\title{
水酸化物由来 $\mathrm{BeO}$ 粉末の表面構造
}

\author{
池上隆康・森 泰道・松田伸一・鈴木弘茂* \\ (科学技術厅 無機材質研究所, *東京工業大学)
}

\section{Surface Structures of BeO Powders Derived from Hydroxide}

By

Takayasu IKEGAMI, Yasumichi MORI, Shin-ichi MATSUDA and Hiroshige SUZUKI*

(National Institute for Researches in Inorganic Materials, *Tokyo Institute of Technology)

Surface structures of nonsinterable BeO powders have been studied on the compositions and amounts of gas desorbed from the BeO powders and the adsorption isotherms of water at $25^{\circ} \mathrm{C}$. The $\mathrm{BeO}$ powders were derived from hydroxide. As a result of our study, following conclusions were obtained.

1) The beryllium hydroxide, precipitated homogeneously from sulfate solution, contained many sulfate ions. $\mathrm{SO}$ and $\mathrm{SO}_{2}$ gases were desorbed from the $\mathrm{BeO}$ powders which had been calcined at temperature less than $1000^{\circ} \mathrm{C}$, but little desorption of those occurred above $1000^{\circ} \mathrm{C}$.

2) Surface structures of the BeO powders, calcined lower temperature, were sensitive to outgassing temperature

3) Surface structures of the BeO powders were not sensitive to calcination temperature.

4) The largest amount of the chemical adsorption of water was found in the BeO powder which was calcined at $1000^{\circ} \mathrm{C}$.

5) Outgassing temperature affected strongly the monolayer capacities of physical adsorption of water vapor on the $\mathrm{BeO}$ powders which were calcined at lower temperature, but calcination temperature affected weakly them.

[Received October 31, 1972$]$

\section{1. 緒言}

$\mathrm{BeO}$ 粉末の焼結性と表面との対応に関して湿潤熱か

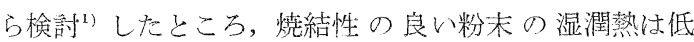

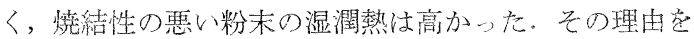

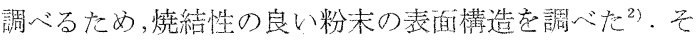
れによると,その表面棈造基本的には(100)面の多い粒 子であることが分った。しかしながら，炍焼温度が変る とその表面構造も大きく変化していた，この変化が BeO 粉末の固有のものであるのか，焼結性の良い粉圭に特有 のものであるのか，興味ある問題である。そこで，焼結

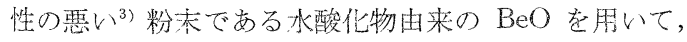
前報と同じ方法で表面構造や表面状態を調べ，その結果 と前報の結果を比較してみたところ興哧ある結諭が得ら れた。

\section{2. 害験}

2.1 試料 溶媒抽出法によって, 市販の特級硫酸ベリリウムをさ らに純度を上げ，高純度硫酸ベリリウム溶液とし，アセ
チルアセトンを用いた均一沈澱法で水酸化ベリリウムを 得た。この方法は前報2)で用いた方法とまったく同じで あり，最終的に硫酸ベリリウム孝調製する前の段階の水 酸化べリリウムにしたところで止めたもので女る。

これを前報 ${ }^{1)}$ 己同じ条件で種々の温度に加熱して炍焼 した. 得られた $\mathrm{BeO}$ 粉末は炍焼温度をつけて区別し

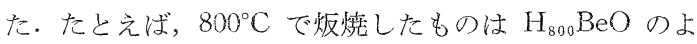
らに表わすことにした。

\section{2 測定方法}

比表面積の測定 ${ }^{1)}$ ，脱ガス量挔よび組成や等温吸着量 の測定方法や計算はすべて前報2) と同じである。

\section{3. 結果}

各炍焼温度で得た $\mathrm{BeO}$ 粉末の粒径は, 図-1 から分 るように，炍焼温萃が約 $800^{\circ} \mathrm{C}$ 以下では，炍焼温度が 高くなると粒径も非常に大きくなっていた。しかしなが ら，800 $\mathrm{C}$ 以上では，炍焼温度が高くなっても女まり大 きくなっていなかった。

各脱気温度範国における各粉末心らの単位重量当りの 


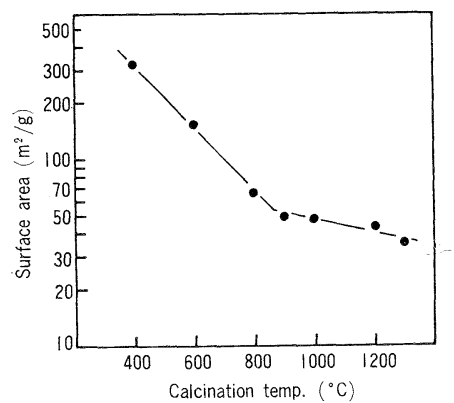

Fig. 1. Surface area as a function of calcination temperature.

Table 1. Amount of gas desorbed from $\mathrm{BeO}$ powders.

\begin{tabular}{|c|c|c|c|c|c|}
\hline & Sample & $\mathrm{H}_{800} \mathrm{BeO}$ & $\mathrm{H}_{900} \mathrm{BeO}$ & $\mathrm{H}_{1000} \mathrm{BeO}$ & $\mathrm{H}_{1200} \mathrm{BeO}$ \\
\hline \multirow{5}{*}{ Temp. } & $200 \sim 400$ & 4.7 & 2.9 & 3.4 & 3.6 \\
\hline & $400 \sim 600$ & 2.4 & 1.2 & 1.7 & 1.8 \\
\hline & $600 \sim 800$ & 1.3 & 1.3 & 0.80 & 0.86 \\
\hline & $800 \sim 1000$ & 2.0 & 1.0 & 0.20 & 0.53 \\
\hline & $(1000 \sim 1100$ & 0.3 & 0.5 & 0.09 & 0.06 \\
\hline
\end{tabular}

(CC at N.T.P./weight)

脱ガス量 $\left(O_{W}\right)$ は，表-1 から分るように，一部をのぞ いて，炍焼温度が高くなるほど少なくなっていたしか しながら， $\mathrm{H}_{1000} \mathrm{BeO} の O_{W}$ は $\mathrm{H}_{1200} \mathrm{BeO} の O_{W}$ より 少なかった。

$1000^{\circ} \mathrm{C}$ 以下で炍焼した粉末のある脱気温度範囲をの ぞいて, 脱ガス量は脱気温度が高くなるほど減少してい た.

脱気温度が高くなっても，脱ガス量が多かった温度範 囲は, $\mathrm{H}_{800} \mathrm{BeO}$ が $800^{\circ} \sim 1000^{\circ} \mathrm{C}$ 間, $\mathrm{H}_{900} \mathrm{BeO}$ が $600^{\circ}$ $\sim 800^{\circ} \mathrm{C}$ 間であった。

表-1 から $100 \AA^{2}$ 当りの脱ガス量 $\left(O_{A}\right)$ に掺算する と, 表-2 が得られた. 表-2 から次のことが分った。

Table 2. Amount of gases desorbed from $\mathrm{BeO}$ powders.

\begin{tabular}{|c|c|c|c|c|c|}
\hline Temp. & Sample & $\mathrm{H}_{800} \mathrm{BeO}$ & $\mathrm{H}_{900} \mathrm{BeO}$ & $\mathrm{H}_{1000} \mathrm{BeO}$ & $\mathrm{H}_{1200} \mathrm{BeO}$ \\
\hline \multirow{4}{*}{$200 \sim 400$} & total & 1.9 & 1.6 & 1.9 & 2.3 \\
\hline & $\mathrm{OH}+\mathrm{H}_{2} \mathrm{O}$ & 1.8 & 1.5 & 1.8 & 2.1 \\
\hline & $\mathrm{CO}+\mathrm{CO}_{2}$ & 0.1 & 0.1 & 0.1 & 0.2 \\
\hline & $\mathrm{SO}+\mathrm{SO}_{2}$ & - & - & - & - \\
\hline \multirow{4}{*}{$400 \sim 600$} & total & 0.99 & 0.67 & 0.99 & 1.09 \\
\hline & $\mathrm{OH}+\mathrm{H}_{2} \mathrm{O}$ & 0.95 & 0.64 & 0.92 & 0.99 \\
\hline & $\mathrm{CO}+\mathrm{CO}_{2}$ & 0.04 & 0.02 & 0.03 & 0.07 \\
\hline & $\mathrm{SO}+\mathrm{SO}_{2}$ & - & - & 0.02 & - \\
\hline \multirow{4}{*}{$600 \sim 800$} & total & 0.51 & 0.71 & 0.47 & 0.55 \\
\hline & $\mathrm{OH}+\mathrm{H}_{2} \mathrm{O}$ & 0.33 & 0.66 & 0.44 & 0.53 \\
\hline & $\mathrm{CO}+\mathrm{CO}_{2}$ & 0.07 & 0.02 & 0.02 & 0.02 \\
\hline & $\mathrm{SO}+\mathrm{SO}_{2}$ & 0.11 & 0.03 & - & - \\
\hline \multirow{4}{*}{$800 \sim 1000$} & total & 0.81 & 0.57 & 0.11 & 0.33 \\
\hline & $\mathrm{OH}+\mathrm{H}_{2} \mathrm{O}$ & 0.06 & 0.26 & 0.07 & 0.22 \\
\hline & $\mathrm{CO}+\mathrm{CO}_{2}$ & 0.05 & 0.07 & 0.03 & 0.07 \\
\hline & $\mathrm{SO}+\mathrm{SO}_{2}$ & 0.70 & 0.24 & 0.01 & 0.04 \\
\hline \multirow{4}{*}{$1000 \sim 1100$} & tatal & 0.15 & 0.30 & 0.05 & 0.04 \\
\hline & $\mathrm{OH}+\mathrm{H}_{2} \mathrm{O}$ & 0.06 & 0.05 & 0.04 & 0.02 \\
\hline & $\mathrm{CO}+\mathrm{CO}_{2}$ & 0.01 & 0.02 & 0.01 & 0.02 \\
\hline & $\mathrm{SO}+\mathrm{SO}_{2}$ & 0.07 & 0.22 & - & - \\
\hline
\end{tabular}

(molecules $/ 100 \AA^{2}$ )
1) $200^{\circ} \sim 400^{\circ} \mathrm{C}$ および $400^{\circ} \sim 600^{\circ} \mathrm{C}$ 間で脱着してく る $O_{A}$ は, $\mathrm{H}_{1200} \mathrm{BeO}>\mathrm{H}_{1000} \mathrm{BeO}>\mathrm{H}_{800} \mathrm{BeO}>\mathrm{H}_{900} \mathrm{BeO}$ の順であり， $\mathrm{H}_{900} \mathrm{BeO}$ の $O_{A}$ が最も少なかった。

2) $600^{\circ} \sim 800^{\circ} \mathrm{C}$ 間では $\mathrm{H}_{900} \mathrm{BeO}>\mathrm{H}_{1200} \mathrm{BeO}>\mathrm{H}_{800}$ $\mathrm{BeO}>\mathrm{H}_{1000} \mathrm{BeO}$ の順で, $\mathrm{H}_{900} \mathrm{BeO}$ の $O_{A}$ は1) とは逆 に最も多かった。

3) $800^{\circ} \sim 1000^{\circ} \mathrm{C}$ 間では, $\mathrm{H}_{800} \mathrm{BeO}>\mathrm{H}_{900} \mathrm{BeO}>\mathrm{H}_{1200}$ $\mathrm{BeO}>\mathrm{H}_{1000} \mathrm{BeO}$ の順で, $\mathrm{H}_{800} \mathrm{BeO}$ の $O_{A}$ が特に多か った。

4) $1000^{\circ} \sim 1100^{\circ} \mathrm{C}$ 間では, $\mathrm{H}_{900} \mathrm{BeO}>\mathrm{H}_{800} \mathrm{BeO}>\mathrm{H}_{1000}$ $\mathrm{BeO}>\mathrm{H}_{1200} \mathrm{BeO}$ の順であった. $1000^{\circ} \mathrm{C}$ までは, $\mathrm{H}_{1200}$ $\mathrm{BeO}$ の脱ガス 量は割合に多かった。しかし，1000〜 $1100^{\circ} \mathrm{C}$ 間で脱着してくるガスは，他の粉末に比べても 非常に少なかった。

表-2 の值をもとに, $200^{\circ} \mathrm{C}$ から各脱気温度までに脱 着してくる脱ガス量を, 各脱気温度に対し点緅する。そ の曲線から傾きを出す。一例を図-2 に示す. 傾きはそ の温度において, 温度が $1^{\circ} \mathrm{C}$ 変化するときの脱着量の変 化である。その傾きを各脱気温度に対し，再び点緅する と，図-3〜6のようになった。これらから分るように， 各粉末とも $600^{\circ} \mathrm{C}$ を境にして, 脱着の仕方が変ってい ることが分る。まず， $600^{\circ} \mathrm{C}$ 以下で脱着してくるものに ついて述べると，次のようになる。

図-3〜6 から分るように, 脱ガス量は脱気温度が高く

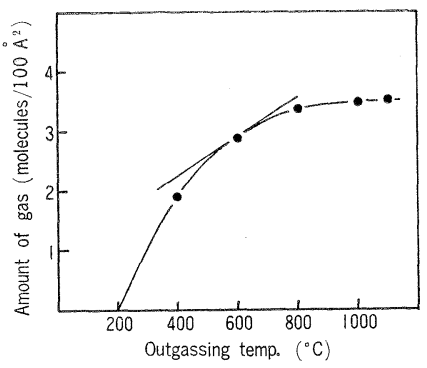

Fig. 2. Amount of gas desorbed from $\mathrm{H}_{1000} \mathrm{BeO}$.

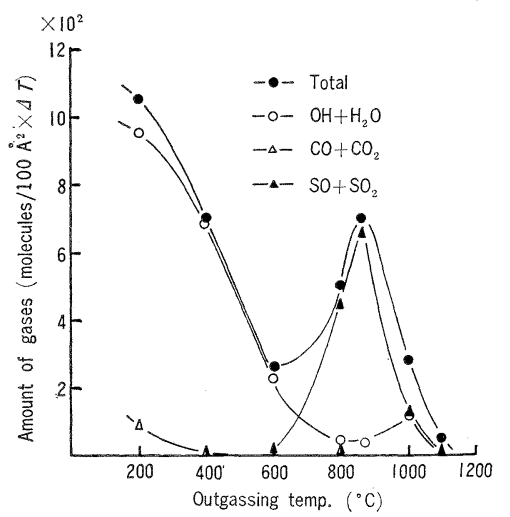

Fig. 3. Amount of gases desorbed from $\mathrm{H}_{800} \mathrm{BeO}$ as a function of outgassing temperature. 


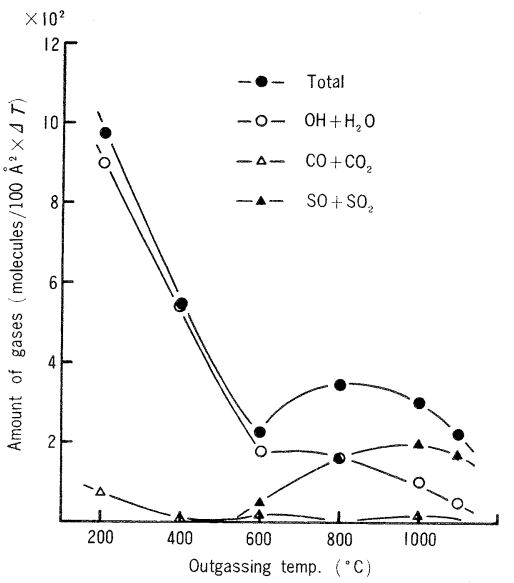

Fig. 4. Amount of gases desorbed from $\mathrm{H}_{900} \mathrm{BeO}$ as a function of outgassing temperature.

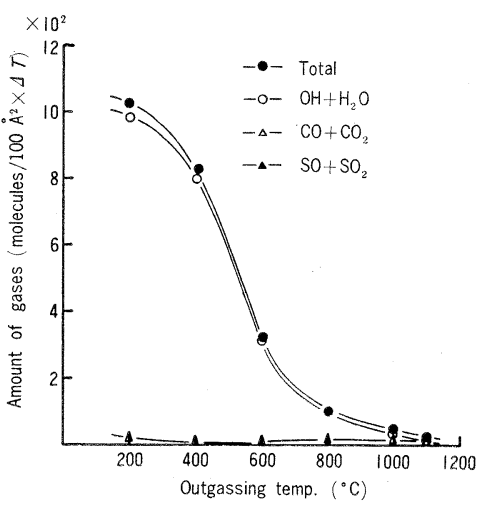

Fig. 5. Amount of gases desorbed from $\mathrm{H}_{1000} \mathrm{BeO}$ as a function of outgassing temperature.

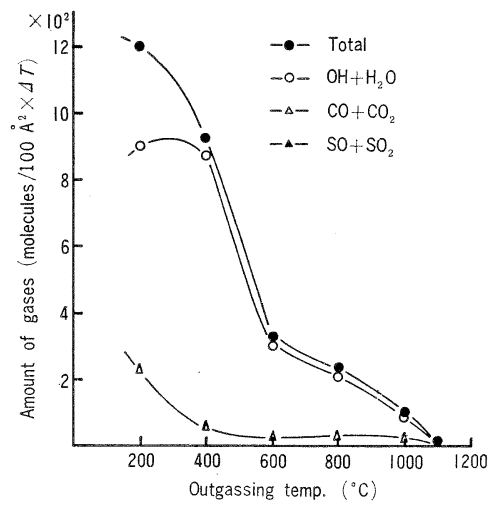

Fig. 6. Amount of gases desorbed from $\mathrm{H}_{1200} \mathrm{BeO}$ as a function of outgassing temperature.

なるほど減少していた。しかも， $\mathrm{H}_{1200} \mathrm{BeO}$ をのぞいて， その脱ガスの組成は $\mathrm{OH}$ や $\mathrm{H}_{2} \mathrm{O}$ が大部分であった. しかしながら， $\mathrm{H}_{1200} \mathrm{BeO}$ は $\mathrm{OH}$ や $\mathrm{H}_{2} \mathrm{O}$ と共に $\mathrm{CO}$ や $\mathrm{CO}_{2}$ も多く, 特に, 約 $300^{\circ} \mathrm{C}$ 以下で脱着してくる ガスの組成は， $\mathrm{OH}$ や $\mathrm{H}_{2} \mathrm{O}$ は減少の傾向にあり， $\mathrm{CO}$ や $\mathrm{CO}_{2}$ がかわりに多くなっていた.
一方，脱気温度が $600^{\circ} \mathrm{C}$ 以上について比較してみる と, 次のことが分る.

$\mathrm{H}_{800} \mathrm{BeO}$ の脱ガス量は, $600^{\circ} \mathrm{C}$ 付近から脱気温度が 高くなると逆に増加し， $900^{\circ} \mathrm{C}$ 付近で極大になる．これ は図-3 から分るように, $\mathrm{SO}$ や $\mathrm{SO}_{2}$ の脱着が $600^{\circ} \mathrm{C}$ 付近から急に増加し, $900^{\circ} \mathrm{C}$ 付近で最も多くなったため である。

$\mathrm{OH}$ や $\mathrm{H}_{2} \mathrm{O}$ の脱ガス量は，やはり脱気温度が高くな るほど減少していた。

$\mathrm{H}_{900} \mathrm{BeO}$ からの $\mathrm{SO}$ や $\mathrm{SO}_{2}$ の脱着が始まる温度は， もっと高温側にずれ，量的にも少なくなっていた。かわ りに, $\mathrm{OH}$ や $\mathrm{H}_{2} \mathrm{O}$ が増加している.

$\mathrm{H}_{1000} \mathrm{BeO}$ や $\mathrm{H}_{1200} \mathrm{BeO}$ からは $\mathrm{SO}$ や $\mathrm{SO}_{2}$ の脱着は ほとんどなく， $\mathrm{OH}$ や $\mathrm{H}_{2} \mathrm{O}$ が大部分であった。 また， $\mathrm{H}_{1200} \mathrm{BeO}$ の脱ガスは，脱気温度が $1100^{\circ} \mathrm{C}$ 以上ではほ とんごないことが分った。

等温吸着量の測定によると，図-7,8 から，次のこと が分った。

脱気温度 $600^{\circ} \mathrm{C}$ で処理した粉末の $100 \AA^{2}$ 当りの物 理吸着量 $\left(A_{p}\right)$ は, 炍焼温度によらず約 5.2 個/100 $\AA^{2}$ でほぼ一定であった。しかしながら，脱気温度の影響は 大きく, 特に, $\mathrm{H}_{800} \mathrm{BeO}$ や $\mathrm{H}_{1000} \mathrm{BeO}$ の $A_{p}$ は脱気温 度が高くなると, 急江増加していた。 $A_{p}$ の増加の仕方 は一部をのぞいて, $A_{c}+V_{c}{ }^{\prime}\left(A_{c}: 100 \AA^{2}\right.$ 当りの水の化 学吸着量, $V_{c}^{\prime}$ : 各脱気温度から $1100^{\circ} \mathrm{C}$ までに脱着し た $100 \AA^{2}$ 当りのガス量, $A_{c}+V_{c}^{\prime}$ : 全化学吸着量) と 逆の傾向にある. 図-8 加ら分るように, 脱気温度 $600^{\circ} \mathrm{C}$ での $A_{c}$ および $A_{c}+V_{c}^{\prime}$ は， $\mathrm{H}_{1000} \mathrm{BeO}$ のそれが最も

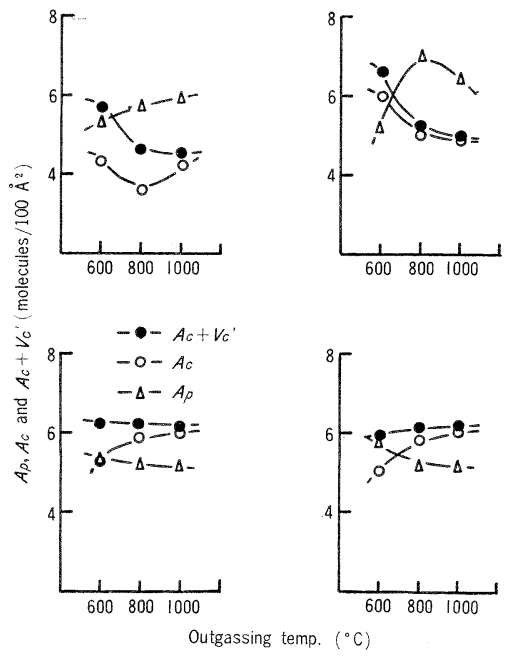

$A_{p}$ : physical adsorption of water vapor at $25^{\circ} \mathrm{C}$ $A_{c}$ : chemical adsorption of water vapor at $25^{\circ} \mathrm{C}$ $V_{c}^{\prime}$ : amount of chemical adsorption on the $\mathrm{BeO}$ powders, outgassed at various temperature

Fig. 7. $A_{p}, A_{c}$ and $A_{c}+V_{c}^{\prime}$ of the $\mathrm{BeO}$ powders pretreated at $600^{\circ}, 800^{\circ} \mathrm{C}$ and $1000^{\circ} \mathrm{C}$. 


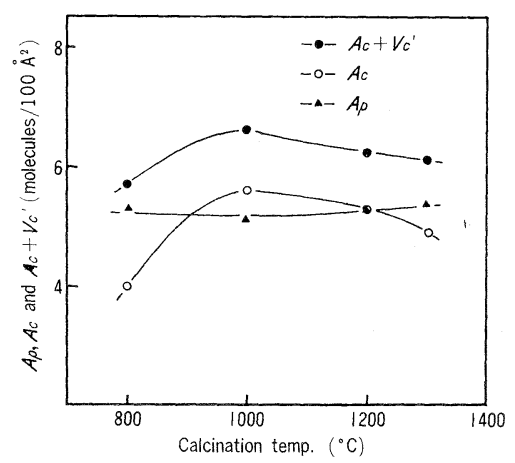

Fig. 8. $A_{p}, A_{c}$ and $A_{c}+V_{c}^{\prime}$ at $600^{\circ} \mathrm{C}$ as a function of calcination temperature.

多かった。上述したよらに, $\mathrm{H}_{800} \mathrm{BeO}$ や $\mathrm{H}_{1000} \mathrm{BeO}$ の $A_{c}+V_{c}{ }^{\prime}$ は脱気温度が高くなると, 急に激少していた. 一方, $\mathrm{H}_{1200} \mathrm{BeO}$ や $\mathrm{H}_{1300} \mathrm{BeO}$ のそれはあまり変化しな かった. 各粉末の $\left(A_{p}+A_{c}+V_{c}^{\prime}\right) / 2$ は脱気温度によら ずほぼ一定の值を示した。

\section{4. 考察}

本実験で測定に用いた粉末の炍焼温度は，おもに 800 ${ }^{\circ} \mathrm{C}$ 以上であるので，炍焼湿度がちがっても，粒子の大 きさはあまりちがいのない温度範囲であった。これらの 粉末の表面の性質を脱ガス量や組成から検討すると, 次 の上らになる。脱気温度が $600^{\circ} \mathrm{C}$ 以上になると, $\mathrm{H}_{800}$ $\mathrm{BeO}$ から $\mathrm{SO}$ や $\mathrm{SO}_{2}$ の脱着が始まり, 脱気温度が高 くなると急に多くなっていた。

水酸化物由来の $\mathrm{BeO}$ に $\mathrm{SO}$ や $\mathrm{SO}_{2}$ が存在するの は，一見不思議に思えるが，BeO を調製するなでの過 程を検討古ると，次のように考えられる。

有機溶媒からベリリウムイオンを逆抽出するときに酸 を用いるが，それに硫酸を用いた。アセチルアセトンに よる均一沈澱法を用いて沈降性の良い水酸化物を得て も，X線的にはアモルファスに近い粒子であった，その ため, 多量の硫酸イオンを沈洪物内に取込んでいると考 えられる、しかも, 水洗を充分に行なっても, 残ってい るものがある・

$\mathrm{SO}$ や $\mathrm{SO}_{2}$ の脱着が始まる温度は $600^{\circ} \mathrm{C}$ と高い。こ の温度は無水硫酸ベリリウムの熱分解によって, $\mathrm{BeO}$ になる湿度に近いので, 上述のようにして硫酸イオンを 取込んだ水酸化物の一部が，均一沈洪操作から炍焼し て, BeO となるまでのある段階で硫酸ベリリウムに近 い構造を持ったものになったと考えられる.

参考のため， $600^{\circ} \mathrm{C}$ で炍焼した粉末の脱ガス紊調べて みると，圈-9 から分るよらに， $\mathrm{SO}$ や $\mathrm{SO}_{2}$ の脱着が始 まる温度や脱力゙ス量が極大になる温度は， $\mathrm{H}_{800} \mathrm{BeO}$ よ り低くなっていた。しかも, 単位重量当りばかりでな く, 単位表面積当りの $\mathrm{SO}$ や $\mathrm{SO}_{2}$ の脱ガス量も非常に

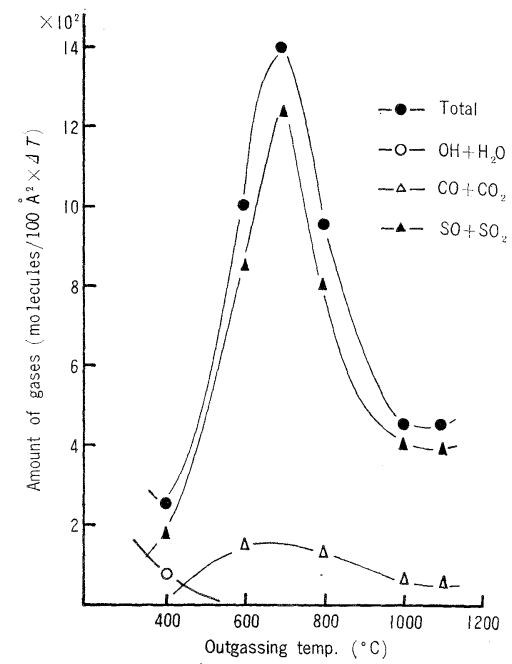

Fig. 9. Amount of gases desorbed from $\mathrm{H}_{600} \mathrm{BeO}$ as a function of outgassing temperature.

多かった・しかし，傾问性はむったく同じであった，特 に, $\mathrm{OH}$ や $\mathrm{H}_{2} \mathrm{O}$ は脱気温度が $600^{\circ} \mathrm{C}$ 以上になると, 全然検出できず，大部分 $\mathrm{SO}$ や $\mathrm{SO}_{2}$ であった。

Cooperstein $^{4}$ やJolibois $5^{5)}$ も水酸化ベリリウムの 調製方法が異なると, その熱分解に顕著な差が認められ ることを報告している。

これらのことから，水酸化べリリウムは沈澱する前の 酸を混入しやすい性質があり, さらに，それを熱分解し ても酸は水酸化物または酸化物と強力に結合しているた め，それらを高温になるまで放出しないと孝えられる。

$\mathrm{H}_{900} \mathrm{BeO}$ からは脱気温度が $600^{\circ} \sim 800^{\circ} \mathrm{C}$ 間でも $\mathrm{SO}$ $\mathrm{SO}_{2}$ の脱着量は少なく, $800^{\circ} \mathrm{C}$ 以上で多くなる。加 りに, $\mathrm{OH}$ や $\mathrm{H}_{2} \mathrm{O}$ が多くなっていた。このことは, 炍 燒温度が高くなるほざ $\mathrm{SO}$ や $\mathrm{SO}_{2}$ が粉末から飛び出 し, その後, 炍焼中, 泠却中ぬたは保存中に, その雾囲 気加ら $\mathrm{OH}$ や $\mathrm{H}_{2} \mathrm{O}$ 表面に吸着, 吸収したことを示 している.

$\mathrm{H}_{1000} \mathrm{BeO}$ の脱ガス組成は, 大部分 $\mathrm{OH}$ や $\mathrm{H}_{2} \mathrm{O}$ で あることから， $\mathrm{H}_{900} \mathrm{BeO}$ とらがい，炍焼中でほぼ完全に $\mathrm{SO}$ や $\mathrm{SO}_{2}$ の脱着が終ったことを示している.しかも， 図-5 から分るよらに, 脱着は低い温度で充分進行して おり, 高温で脱着してくる量は少ない。このことは, 吸 着力の強いサイトは少ないことを示しており, 粉末表面 は安定で不活性な状態にあることを意味している.

$\mathrm{H}_{1200} \mathrm{BeO}$ の脱ガス組成は，脱気温度が低い所で CO や $\mathrm{CO}_{2}$ が多くなっており, $\mathrm{S}_{1100} \mathrm{BeO}$ と似ていた $\mathrm{H}_{1200} \mathrm{BeO}$ と $\mathrm{H}_{1000} \mathrm{BeO}$ の脱ガス量や組成を比較してみ ると, $\mathrm{S}_{1100} \mathrm{BeO}$ と $\mathrm{S}_{1000} \mathrm{BeO}$ の場合と非常に似ている. $\mathrm{CO}$ や $\mathrm{CO}_{2}$ の脱着の傾问ばかりでなく, $200^{\circ} \sim 1000^{\circ} \mathrm{C}$ 間では炍焼温度の高い方が脱ガス量は多いが，1000〜 $1100^{\circ} \mathrm{C}$ 間のそれは逆になっていた。 このことは水酸化 
物由来の $\mathrm{BeO}$ も炍焼温庋が $1000^{\circ} \sim 1200^{\circ} \mathrm{C}$ 閒で表面構 造の変化が始むり, $\mathrm{H}_{1300} \mathrm{BeO}$ の表面構造は $\mathrm{H}_{1000} \mathrm{BeO}$ などのものと大きく違らことが予想される。しかしなが ら，脱ガス量や後述するよらに， $A_{c}$ や $A_{c}+V_{c}^{\prime}$ もほ ぼ同じ值であり， $\mathrm{H}_{1300} \mathrm{BeO}$ のそれらが特に変っている といらことはなかった。それゆえ，硫酸塩由来の $\mathrm{BeO}$ とちがい，炍焼温度が $800^{\circ} \sim 1300^{\circ} \mathrm{C}$ 間での表面構造の 変化は少ないと考えられる。

等温吸着量の測定で, $600^{\circ} \mathrm{C}$ で脱気処理したもののう ち, $\mathrm{H}_{800} \mathrm{BeO} の A_{c}$ が他の粉末のそれに比べ，非常に 少ないのは表-2 から分るよらに， $600^{\circ} \mathrm{C}$ で脱気しても 脱着されずに吸着しているものが多いのも1つの原因で あろら。それらの分子の存在状態は $\mathrm{S}_{900} \mathrm{BeO}$ の場合と 同じく，(1)微細なクラック内に吸着している。(2) 1 個 たは数個の空孔に吸着している. (3)粒子内部に存在して いると考えられる。

表-2 から分るよらに，各粉末とも $1000^{\circ} \sim 1100^{\circ} \mathrm{C}$ 間 で脱着してくるガスは非常に少なく，脱ガス曲線の傾向 性から, $1100^{\circ} \mathrm{C}$ までに大部分の吸着分子は脱着してい ると考えられる。このことは，各温度から $1100^{\circ} \mathrm{C}$ まで に脱着してくる $100 \AA^{2}$ 当りのガス量 $\left(V_{c}^{\prime}\right)$ が，その 温度で脱気しても吸着している $100 \AA^{2}$ 当りの分子数と なる. $A_{c}+V_{c}^{\prime}$ は粉末表面が $25^{\circ} \mathrm{C}$ で水蒸気を吸着した ときの $100 \AA^{2}$ 当りの全化学吸着量である.

前報で述べたように, 吸着分子 1 個が表面の酸素イ才 ン 2 個と吸着すると, $2\left(A_{c}+V_{c}{ }^{\prime}\right)$ が表面で露出してい る $100 \AA$ 当りの酸素 イオンの数になる.脱気温度が $600^{\circ} \mathrm{C}$ での $A_{c}+V_{c}^{\prime}$ を比較すると, 図-8 から分るよ うに, $\mathrm{H}_{1000} \mathrm{BeO}$ は 6.6 個 $/ 100 \AA^{2}$ で最も多く, $\mathrm{H}_{800} \mathrm{BeO}$ は 5.7 個 $/ 100 \AA^{2}$ で最も少なかった。これは硫酸塩由来 の $\mathrm{BeO}$ よりも表面に露出している酸素イオンの少ない ことを意味し，水酸化物由来の $\mathrm{BeO}$ の表面 ${ }^{6)}$ は (101) 面などのイオンの少ない面が多いことになる. $\mathrm{H}_{800} \mathrm{BeO}$ や $\mathrm{H}_{1200} \mathrm{BeO}, \mathrm{H}_{1300} \mathrm{BeO}$ の $A_{c}+V_{e}{ }^{\prime}$ が $\mathrm{H}_{1000} \mathrm{BeO}$ のそ れに比べ少ないのは，次のことが考えられる。

1） $V_{c}^{\prime}$ を少なめに評価している．2）不純物，空孔， クラックなどによる歪. 3) 表面の面指数が違う．4） $600^{\circ} \mathrm{C}$ で脱気処理したため, 表面が水蒸気に対し, 不活 性になった。

\section{$\mathrm{H}_{800} \mathrm{BeO}$ について検討する.}

表-2 や図-3 から分るように, $\mathrm{H}_{800} \mathrm{BeO}$ は脱気温度が $1100^{\circ} \mathrm{C}$ 以上でも脱着してくるガスがあると考えられる ので，1）の影響もある。このことと $800^{\circ} \sim 1000^{\circ} \mathrm{C}$ 間で 多量の脱ガスがあることから，表面は非常に乱れている と考えられ 2) の影響もある。電子顕微鏡写真による と，炍燒温度が $1000^{\circ} \mathrm{C}$ のものと似ているので，3）の 影響は少ない, 四-7から分るように, 脱気温度が $600^{\circ} \mathrm{C}$ 以下でも $A_{c}+V_{c}^{\prime}$ は増加の傾向にあるので，4）の影響
もある・

一方, $\mathrm{H}_{1200} \mathrm{BeO}$ や $\mathrm{H}_{1300} \mathrm{BeO}$ の $A_{c}+V_{c}{ }^{\prime}$ について 検討すると， $A_{c}+V_{c}{ }^{\prime}$ が少ないのは，3）によると考え られる。

$600^{\circ} \mathrm{C}$ で脱気処理した水酸化物由来の $\mathrm{BeO} の A_{c}+$ $V_{c}^{\prime}$ は, 硫酸塩由来の $\mathrm{BeO}$ に比べて, 炋焼温度が変っ てもあまり変化しない。それゆえ, 表面構造は炍焼温度 によらず非常に似ていることを示している。

脱気温度が高くなると, $A_{c}+V_{c}^{\prime}$ は減少する。これは 脱気温度が高くなると, 熱エネルギーのため, 表面が水 蒸気に対し不活性になったことを示している.特に,炍焼 温度の低い方でそれが顕著であった． $\mathrm{H}_{1200} \mathrm{BeO}$ や $\mathrm{H}_{1300}$ $\mathrm{BeO}$ の $A_{c}+V_{c}{ }^{\prime}$ は脱気温度によらずほぼ一定であった ことは, 炍燒温度が高いため, なたは, 炍焼雾囲気との 相互作用で表面にある種の変化が起り, 脱気温度にはあ まり影響を受けない表面になったと考えられる。その内 容については検討中である。

$A_{p}$ は脱気温度によって非常に違っておうり, 炍燒温度 が低い方で顕著である。しかも, 脱気温度による $A_{p}$ の 変化は大部分 $A_{c}+V_{c}^{\prime}$ と逆の関係になっていた。この ことは, $A_{c}+V_{c}^{\prime}$ の変化が $A_{p}$ にも影響していること を示していると考えられる。

上述したように, $A_{c}+V_{c}^{\prime}$ の減少は, 粉末表面の一部 が熱エネルギーによって不活性になり, 吸着力の弱いサ イトとなったため， $25^{\circ} \mathrm{C}$ で $10^{-5}$ Torr 以上に真空引き した時, そのよらなサイトに吸着していた水分子が脱着 してくるためと考えられる。このことは, それらの表面 には $\mathrm{H}_{2} \mathrm{O}$ が吸着している部分と, 脱着して $\mathrm{BeO}$ 自身 の表面が露出している部分の質的に違らサイトがあるこ とを意味している. BET の式7) は均質な表面を前提に しているため, 表面に質的に違らサイトがあると, $A_{p}$ の值も変ってくると考えられる.

$A_{c}+V_{c}{ }^{\prime}$ が大きく出る脱気温度では, 脱気処理によっ て脱着サイトが不活性になるサイトは少ないから， $25^{\circ} \mathrm{C}$ で真空脱気しても粉未表面は $\mathrm{H}_{2} \mathrm{O}$ で覆われていると考 えられる. 粉末小表面構造の変化は化学吸着層によって 弱められ，さらに，水酸化物由来の $\mathrm{BeO}$ のように，女 まり炍焼温度によって表面構造が変化しない粉末表面の $A_{p}$ の值は，炍焼温度によらないと考えられる.図-8 はこのことを示している。

脱気温度が $600^{\circ} \mathrm{C}$ に打汀 $A_{c}+V_{c}^{\prime}$ と, $200^{\circ} \sim 1100$ ${ }^{\circ} \mathrm{C}$ 間で脱着してくるガスの量の差が，ほぼ $200^{\circ} \mathrm{C}$ 以下 で脱着した化学吸着していた分子数となる. $\mathrm{H}_{800} \mathrm{BeO}$

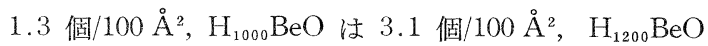
は 1.9 個 $/ 100 \AA^{2}$ となる. このことからも, $\mathrm{H}_{1000} \mathrm{BeO}$ の表面は非常に不活性な面であることが分る。 
5. 総括

水酸化物由来の $\mathrm{BeO}$ からの脱ガス量および組成，等 温吸着量の測定から次のことが分った。

1）水酸化物由来の $\mathrm{BeO}$ の表面は，水酸化物の沈澱 をつくる前の酸の影響が残る。

2) 炍焼温度が $1000^{\circ} \mathrm{C}$ の粉末が水蒸気に対し不活性 な表面であり，それより低い温度では，水酸化物を沈澱 させる前の酸の影響, それより高い温度は炍焼温度や雾 囲気の影萻萃面は活性となる。

3）水酸化物由来の $\mathrm{BeO}$ 粉末の $A_{c}+V_{c}{ }^{\prime}$ は硫酸塩 由来の $\mathrm{BeO}$ 粉末に比べ少なく, 表面に露出している酸 素イオンは少ないと考えられる.さらに, 炍焼温度によ る $A_{c}+V_{c}^{\prime}$ の変化は前者の方が少なかった。

4) $A_{p}$ は炍焼温度よりも脱気温度によって変り，そ
の変化は $A_{c}+V_{c}^{\prime}$ と逆であった。

\section{文献}

1）池上隆康，松田伸一，鈴木弘茂，窝協 81 [8] 322-26 (1973).

2）池上隆康，森 泰道，松田伸一，鈴木弘茂，窯協81 [9] 379-82 (1973).

3) T. Hattori, H. Suzuki, Bulletin of the Tokyo Institute of Technology, [90] 91 (1969).

4) R. Cooperstein, UCRL-6725 (1962).

5) P. Jolibois, M. Bergés, Comp. rend. 224, 79 (1947).

6) R.W.G. Wyckoff, "Crystal Structures" vol. 1, John Wiley \& Sons (1963) p. 112.

7) S. Brunauer, P.H. Emmett, E. Teller, J. Am. Chem. Soc. 60, 309 (1838).

(10/31/1972 受付) 